\title{
Silver Halides in the Hypergene Zone of the Arkharly Gold Deposit as Indicators of their Formation in Dry and Hot Climate (Dzungar Alatau, Kazakhstan)
}

\author{
Zamzagul T. Umarbekova1, Geroy Zh. Zholtayev', Bakytzhan B. Amralinova ${ }^{2}$ and Indira E. Mataibaeva ${ }^{2}$ \\ ${ }^{1}$ Satbayev University, Institute of Geological Sciences named after K.I.Satbayev, Republic of Kazakhstan. \\ ${ }^{2}$ D.Serikbayev East Kazakhstan State Technical University, Republic of Kazakhstan.
}

\begin{abstract}
Oxidation of the ores from the Arkharly deposit was favored under the conditions of the dry and hot climate in the Paleozoic, leading to dissolution of gold and silver, their migration in acid solutions and further deposition on appropriate geochemical barriers, when opportunity arose for sedimention of hardly soluble salts of chlorides, bromides and iodides. Described are interesting findings of silver halide minerals in the oxidation zone of the Arkharly deposit, in a state of accretions with native silver and gold. Native silver, gold and silver-containing sulphides are sources of silver for halide minerals, as witnessed by their zonal accretions. Among silver halide minerals, identified in thin rims were chlorargyrite, brome iodide, embolite, and iodyrite. The hypergene nature of gold is indicated by its close paragenesis with silver and silver halides.
\end{abstract}

Keywords: Arkharly, gold, native silver, hypergene, deposit, halide, weathering crust.

\section{INTRODUCTION}

The epithermal gold-silver deposit Arkharly, in terms of geological structure, ore deposition conditions and mineral composition, is analogous to the world famous large- and medium-sized deposits of this geological and industrial type (Cripple Creak, Angostura, Yanocoha, KochBulak and oth.), which are characterized by connection in space and time with volcanoplutonic formations and the localization in volcanic and volcanic-tectonic structures.

Formation of silver halide minerals is related to climate and reflects the increased concentrations of halide elements in the waters of dry regions. Silver halides are rare or totally absent in deposits of Europe. Similarly, they were not detected reliably in the North and Middle Urals, the Caucasus and Transbaikalia.

High concentration of chlorine in ground waters of Kazakhstan's deposit fields reflects climatic conditions of this area. Sources of chlorides and other salts, contained in ground waters are weathering rocks. The endorheic nature of Central Kazakhstan and the dryness of its climate, both in the past and in the present, favoured the ultimate accumulation of salts in ground waters, in the waters of multiple lakes and endorheic river reservoirs. Concentration of salts in ground waters increases with the move of water up the capillaries to the surface. Water evaporates, and salts are released with formation of both surface and internal solonchaks, localised somewhat beneath the surface. Salts of solonchaks are brought by rain showers back to the ground waters zone. The capillary move of solutions to the surface increases the amount of chlorine ions by reduction of the number of sulphate ions. This happens because solution cations displace the calcium of the soil in the bound state. The compound of this calcium with sulphate ions is a poorly soluble sulphate, which largely precipitates from the solution. Therefore, under conditions of Central Kazakhstan, the amount of chlorides, because of the capillary lift, increases in the ground waters.

\section{GEOLOGICAL SITUATION}

The Kazakhstan deposits of gold-silver adular subformation are confined to the Upper Paleozoic volcanic-tectonic ring structures. Their arrangement is principally affected by the deep fault zones (Dauletbai, Kalmak-Emel and oth.), largely hidden under the Upper Paleozoic volcanic structures (fig. 1B). The fault zones are represented by a series of sub-parallel oriented rupture disturbances, along which intrusions occur of dikes and subvolcanic bodies [1].

Among gold-silver formations, the youngest are deposits of the southwest part of the Dzungarian Alatau. Syromyatnikov N.G., Koshevoi O.G. and oth., established that, according to superposition of the mineralisation on the Permian - Lower Triassic rhyolite-basalt formations and the data of lead-isotope studies, the average value of a model age of lead from galenite in 8 samples is $240 \pm 4$ million years, which unambiguously points to the Late Permian - Early Triassic age of the ore. The Arkharly deposit is the most typical representative of the formation in the region (fig. 1 A-B). There are explicit overlaps of mineralisation on the dikes of lamprophyre series at ore sites of the deposit, intruded into Permian-Triassic accumulations [2].

Ore-bearing quartz veins connect, like a coupling link, the echelonised tear cracks, developed over the shifts of the volcanic structure basement and in a certain degree subordinated to the elements of volcanic-tectonic ring structures.

The following features are characteristic to gold-silver deposits: 1) close structural-paragenetic connection of shallow 
gold mineralisation with magmatism of orogenic volcanoplutonic belts of Kazakhstan, with which it constitutes a single magmatogenic-ore; 2) confinement of deposits to zones of long-lived deep faults, cutting through the complex systems of paleo-volcanic structures, to fragments of concentric and radial faults of volcanic-tectonic ring structures, to specific ore-bearing explosive structures, often combined with centres of volcanic build-ups; 3) wide distribution of fields of epidote-actinolite-chlorite propylites or lowtemperature secondary quartzites, serving as one of signs for delineation of areas of development of gold-adular-quartz mineralisation; 4) availability of wallrock metasomatites proper of adular-quartz and hydromicaceous-quartz composition, primary dissipation halos of $\mathrm{Au}, \mathrm{Ag}, \mathrm{Pb}, \mathrm{Zn}, \mathrm{Cu}$, $\mathrm{Bi}$, Mo, As, extensive potassium halos, as well as clearly expressed mineralogical and geochemical zonality of mineralization; 5) significant variability in the $\mathrm{Ag} / \mathrm{Au}$ ratio of ores from different deposits, with relatively small values of gold fineness.

\section{CHARACTERICTICS OF HYPOGENE MINERAL FORMATION}

The Arkharly gold-silver deposit is a typical epithermal volcanic hydrothermal deposit. Within its ore field, in the area of 8.0 x 3.5 sq.km, several industrial sites (Central, East I and II, North-East, Kyzyl-Shoky) have been allocated.

The main vein materials within each of them are fine-grained metacolloid quartz, amethyst and chalcedony. The goldbearing veins contain adular, silver sulphides and low-grade gold. Polysulphide mineralisation, predominance of sphalerite and pyrite, abundance of hypogene hematite and the pink colour of adular are characteristic. The following zones were identified as the mineral associations:

Grebenchikov A.M. distinguished the multi-temporal mineral paragenetic associations as follows (from the early to the late ones): 1) pyrite quartz, 2) adular quartz, 3) galenite-sphaleritequartz, 4) chalcopyrite quartz, 5) chalcedony, 6) carbonatezeolite, and 7) barite. The productive gold associations are adular-quartz and galenite-sphalerite-quartz [3].
(A)

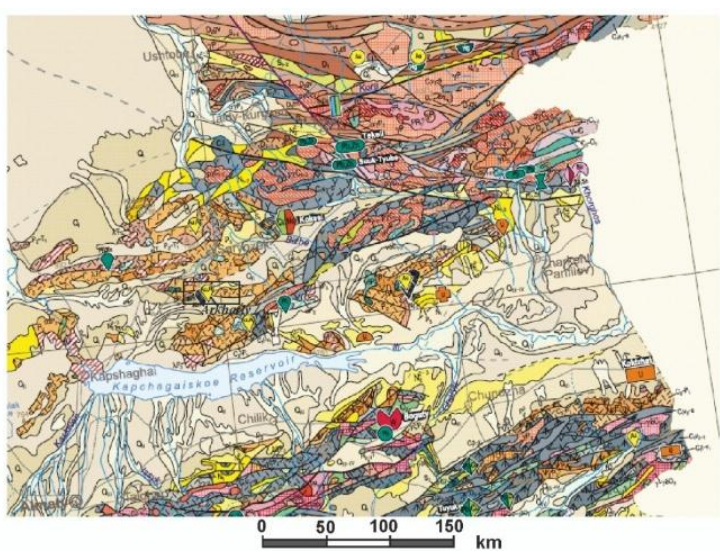

1: 2500000
(B)

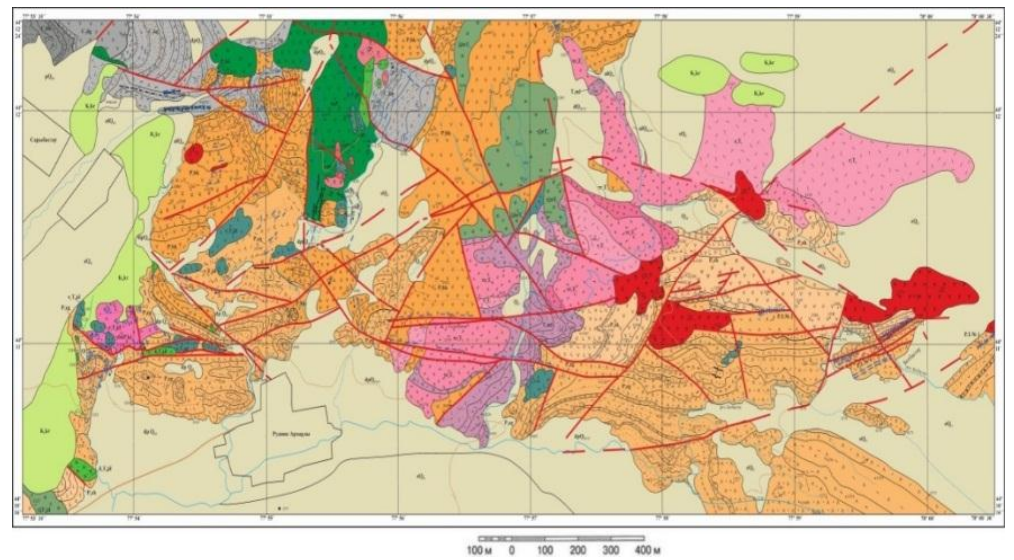

$1: 10000$

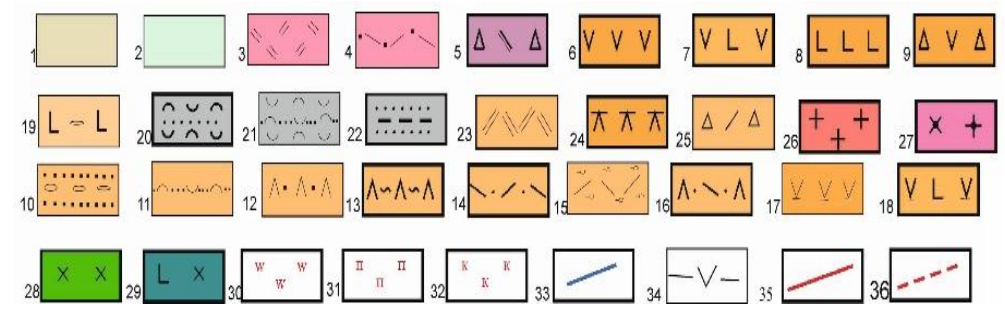

Stratified formations: 1. Quaternary deposits; 2. Neogene pebblestone and clays; Triassic deposits, trachyrhyolites of the MalaiSary suite $\mathrm{T}_{1} \mathrm{ml}: 3$ - lava, 4 - tuff, 5 - nearmouth breccias; Permian deposits, the ZheldyKora suite $\mathrm{P}_{2}$ zk: 6 - andesite, 7 - basaltic andesite; 8 - basalt, 9 - andesite clastic flow, 10 - sandstone conglomerates; the ZhalgyzAgash suite $\mathrm{P}_{1} \mathrm{zg}$ : 11 - tuff sandstone, 12 - dacite tuff, 13 - dacite tuff lava, 14 - rhyolite tuff, 15 - ignimbrite, 16 - riodacite tuff; the BesKainar suite $\mathrm{P}_{1}$ bk: 17 - plagioandsite, 18 - pyroxene plagioclase basaltic andesite, 19. basaltic slag; the Kugaly suite $\mathrm{C}_{3} \mathrm{Kg}$ : 20 - thin alternation of sandstone and tuff sandstone, 21 - tuff sandstone interlaid with tuffite, 22 - sandstone interlaid with aleurolites, 23 - KyzykShoky necks, 24 - subvolcanic dacite, 25 - KyzykShoky mouth and nearmouth breccias. Intrusive rocks of the South Dzungar complex: 26 - granit porphyry, 27 - granodiorite porphyry, 28 - diorite; the SaryBulak complex: 29 - gabbrodiabase. Other designation: 30 - subvolcanic trachy-andesite body, 31 - secondary quartzite, 32 - propylite, 33 - kalifeldspathised rock, 34 - gold bearing quartz veins, 35 - dike; 36 - certain fault, 37 - fault covered by loose deposits

Fig. 1. Geological maps of Central Asia and adjacent areas [10] (A) and of the Arkharly ore field (B) [11]. 
Each mineral association either composes independent veins, spatially separated and crossing each other, or participates in the composition of complex veins, where formation sequence of different-time associations is observed clearly within one ore body.

The adular-quartz ores are characterised by predominance of the adular-quartz mineral association in their composition. Their gold content ranges from $0.5 \mathrm{~g} / \mathrm{t}$ to $280 \mathrm{~g} / \mathrm{t}$, and of silver up to $156.0 \mathrm{~g} / \mathrm{t}$. The amethyst-quartz ores are characterised by predominance of the galenite-sphalerite-quartz mineral association. Their gold content ranges from 0.1 to $40.0 \mathrm{~g} / \mathrm{t}$, of silver from 0.5 to $125.0 \mathrm{~g} / \mathrm{t}$. It is always possible to distinguish the microscopic impregnation of sulphides in ores (sphalerite, galenite and so on), usually distributed in strips and comprising $0.5-20 \%$ of the ore volume.

The chalcedony ores are composed mainly of the chalcedony mineral association. Their gold content rarely exceeds $0.4 \mathrm{~g} / \mathrm{t}$, and $20 \mathrm{~g} / \mathrm{t}$ of silver. The pyrite-quartz ores are characterised by predominance of the pyrite-quartz association. Their gold content rarely exceeds $0.5 \mathrm{~g} / \mathrm{t}$ and $5 \mathrm{~g} / \mathrm{t}$ of silver. Pyrite is embedded at the $0.5-10 \%$. The hypogene gold was identified in the ores later than the most of the sulphides. Grebenchikov A.M. established gold of 2 generations: gold I in association with pyrite III, chalcopyrite II, sphalerite I and silver sulphides (the adular-quartz association) and gold II in association with galenite II, sphalerite II, pyrite IV, chalcopyritem II, III and other minerals of the galenitesphalerite-quartz association [3].

The gold I grade is 596-635 and of gold II 735-772.

The low-grade gold I has a zonal internal structure (no more than 2-3 zones). Judging by the nature of etching, the gold sample in external zones is always lower.

The facial zonality of ore deposition is expressed clearly. The least eroded part contains weakly gold-bearing drusy and crustified aggregates of quartz, adular, barite and embedded pyrite. Below are the strips of low-sulphide adular-quartz aggregates. As the ore bodies fall, the amount of silver minerals decreases with predominance of sphalerite, electrum, chalcopyrite, and pyrite, while at wedging of veins predominant are pyrite, chalcopyrite, and electrum. Correspondingly, in the direction from the gold-argentite zone to the gold-pyrite-chalcopyrite thin-banded collomorphic texture of the veins is replaced by an unclear-banded and massive one; the content of sulphide, gold, chlorite, adular in the veins decreases; colour of adular changes from orange to light-pink and yellowish, amethyst and barite disappear; the silver-gold ration increases (from 5 to 40); the range of gold sample oscillations and its inclusions decreases; the average purity of gold rises up to 630-750 [4].

Relatively high-grade gold I has a lumpy distorted shape of monocrystals, dendrites, plate particles with spongy surface. It forms often monomineral releases in quartz and occasionally accretions with quartz in the form of spherical, complex subgraphic structure and thin-sponge shapes. The morphology of gold indicates that their crystallisation took place in a viscous (gel-like) medium.

\section{SILVER HALIDE MINERALS AND THEIR DEPENDENCE ON CLIMATIC CONDITIONS}

It is known that silver halides are the most characteristic of areas with dry climate, now or in the past, for example, in South America, where silver halides are encountered in significant concentrations (especially, in Chile). Ores with cerargyrite are abundant in many dry regions of the western USA (New Mexico, Arizona, Yuta, Nevada) [5].

In the south of Kazakhstan, silver halide minerals are found in the Mai-Kain, Zhezkazgan, Zhelambet and Bes-Shoky. Climate there is relatively dry. Ground waters are mineralised, sometimes representing true salt brines.

Chlorine originates from weathered rocks. High concentration of chlorine is established in ground waters of deposit fields of Kazakhstan, reflecting the climatic conditions. Of silver minerals, cerargyrite is widespread; embolite and bromeargyrite are less common, and iodargyrite is even rarer. Where the oxidation zone was formed under a wetter climate, cerargyrite is the only present silver halide. This is explained by insignificant content of iodine and bromine in the waters of districts with humid climate. Chlorine there is much abundant than iodine and bromine and is sufficient for depositing the noticeable amount of silver. Obviously, presence in the oxidation zone of silver bromide and even so of silver iodine is the most important sign of its formation under arid climate conditions [6].

Silver halide minerals originate from hypogenous native silver. For example, the possibility of formation of silver halide minerals in connection to weathering of sulphide minerals was noted by R. Brauns [7]

Observations over the steppe Kazakhstan show, that silver halides in places originate from native gold. The Arkharly deposit is rich in silver halide minerals of hypergene origin.

Abundance of silver halides, known as the outcome of weathering of sulphides, was established in ores of Zhezkazgan.

At pyrite deposits, silver halide compounds were found in sulphur-containing horizons at bottom of oxidation zones (Mai-Kain, Blyava, Rio Tinto) [8]. However, it is most likely, that part of halides in the sulphur-containing horizon emerged as a result of substitution of argentite, formed from descending vadose solutions. It is possible that this process is more widespread and, in addition to argentite in sulphurcontaining horizons, native silver is formed, which then is also 
replaced by halogenides.

Methodology Samples of rocks and minerals from the Arkharly deposit were analyzed in the Laboratory Research Centre at the Natural History Museum (London) and the Satpayev Institute of Geological Sciences (Almaty). Equipment employed were the scanning electron microscope Zeiss EVO 15LS SEM and the electron-probe unit Cameca SX100 in the former place and the microprobe microanalyzer JCXA 733 in the latter.

The chemical composition of the samples (Table 1) was studied in the Satpayev Institute of Geological Sciences, applying the method of the electron-probe microanalysis, using the JCXA 733 and the energy-dispersive spectrometer INCA ENERGY at an accelerating voltage of $15 \mathrm{kV}$, the probe current of $25 \mathrm{nA}$ and the focused probe (1-2 $\mu \mathrm{m}$ in diameter). The following samples were used for comparison: albite (Na), $\mathrm{MgO}(\mathrm{Mg})$; $\mathrm{Al} 2 \mathrm{O} 3(\mathrm{Al})$; $\mathrm{SiO} 2(\mathrm{Si})$; adular $(\mathrm{K})$; $\mathrm{CaSiO} 3$ (Ca); TiO2 (Ti); Fe2O3.MnO (Fe, Mn), metallic ( $\mathrm{Zn}$ ); metallic Zn, V, Nb, Ta, Sn, U, Co (Zn, V, Nb, Ta, Sn, U, Co); ThO2 (Th); SrF2 (Sr); ZrO2 (Zr); CaF2 (F), BaSO4 (Ba), $\mathrm{x}(\mathrm{PO} 4)(\mathrm{x}-\mathrm{REE})$ (table 1). Pictures were taken in the mode of back-sparse electrodes (fig. 2-7).

The Zeiss EVO 15LS SEM is a universal analytical scanning electron microscope, which operates under variable pressure and high vacuum conditions. The low-vacuum mode was used for visualisation and the qualitative $\mathrm{X}$-ray analysis of samples. The pressure was within the range of $60-100 \mathrm{~Pa}$, although it can be increased up to $200 \mathrm{~Pa}$. Minerals were identified by the EDX detector calibrated regularly for the analysis of basic elements in silicates, the most abundant rock-forming minerals; it can quickly provide information, necessary for mineral identifications. The scanning electron microscope was also used to create maps of thin rock sections indicating the distribution of basic and rare elements: $\mathrm{Si}, \mathrm{K}, \mathrm{Al}, \mathrm{P}, \mathrm{Ce}, \mathrm{Nd}$, $\mathrm{Eu}, \mathrm{Gd}, \mathrm{Y}$, and other (fig. 8-12).

The samples (universal thin sections and collars) were analyzed with the use of the electron-probe microscope Cameca SX-100 working on the dispersion wave, widely used in mineralogical and geochemical studies of the Natural History Museum (London). The operating conditions were as follows: $20 \mathrm{kV}$ of accelerating voltage, $20 \mathrm{nA}$ of the beam current and $20 \mu \mathrm{m}$ in the beam diameter. Specific synthetic compounds and natural minerals were used as probe standards. The PAP matrix was corrected upon having made several corrections of peak overlapping. As a result of the electron-probe analysis, the qualitative chemical composition of the minerals was identified (Table 2).

\section{RESULTS}

The hydromicaceous kaolinite type weathering crust within the Arkharly ore field. The present-day weathering crust includes remnants of lower parts of the chalk weathering crust (disintegration zone). Influenced by changes in hydrological and climatic situations during various periods of the region's platform development stage, vertical levels of weathering zones were repeatedly replaced by deposition zones, which resulted in secondary gold enrichment of ore bodies at several levels.

The vertical range of the zone, enriched by hypergene gold and silver, extends for 100-110 m down from the present-day surface. The content of silver varies from 200-450 up to $3632.9 \mathrm{~g} / \mathrm{t}$.

The newly formed hypergene gold at the Arkharly deposit is associated with gematite, limonite, yarozite, malachite, azurite and other minerals of the oxidation zone and is represented by various morphological types. The most common are webbed branch-shaped dendrites with rectangular axes. There are starshaped dendrites consisting of separate tables, corresponding to staged hypergenous mineral formation and different goldenrichment degrees of individual portions of vadose solutions. Often encountered are dust-like gold grains in association with limonite and yarosite in a quartz matrix and rounded zonal formations like Lieseganga rings, probably formed as a result of periodic deposition from gel solutions with participation of electrochemical processes. In addition, fine gold is absorbed by hypergene minerals of iron and manganese. In such new growths, yarosite, while being saturated with gold, changes its colour from ochre-yellow to golden [9].

As a result of detailed microscopic and micro-probe studies of the oxidation zone ores of the Arkharly deposit, for the first time various silver halides and accretions of electrum with native silver were established, and this has a principal importance for restoration of processes of hypergene mineral formation (Table 1).

Figures 2-7 show native gold and silver, in close accretions with silver halides. Most of the grains in the photo have a zonal structure and are composed of various halides and native silver. The mineral composition was determined with the JCXA-733 microprobe. The images were taken in the back-sparse electron mode. Analytical works were carried out by Plekhova K.R., Levin V.L., and Kotel'nikov P.E.

Chlorargyrite $\mathrm{AgCl}$ was found as a frame around the zonal accretion of native silver in the centre with the smallest inclusions of native gold; edged by brome iodide (fig. 2).

Brome iodide $\mathrm{Ag}(\mathrm{Br}, \mathrm{Cl}, \mathrm{I})$ is edging around the rim of chlorargyrite in the zonal accretion (fig. 2). 
International Journal of Engineering Research and Technology. ISSN 0974-3154, Volume 13, Number 1 (2020), pp. 181-190

(C) International Research Publication House. https://dx.doi.org/10.37624/IJERT/13.1.2020.181-190

Table 1. Composition of minerals from Arkhaly according to micro-X-ray spectral analysis (weight, \%)

\begin{tabular}{|c|c|c|c|c|c|c|c|c|c|c|c|c|c|c|c|c|}
\hline$\frac{3}{0}$ & $\underbrace{\stackrel{00}{0}}_{\overparen{0}}$ & एँ & \multicolumn{11}{|c|}{ Elements (wt, \%) } & \multicolumn{2}{|c|}{ Mineral formulas } & \multirow[t]{2}{*}{ Minerals } \\
\hline & & & $\mathrm{Au}$ & $\mathrm{Ag}$ & $\mathrm{Cl}$ & $\mathrm{J}$ & $\mathrm{Br}$ & $\mathrm{Cu}$ & $\mathrm{Fe}$ & $\mathrm{O}$ & $\mathrm{S}$ & $\mathrm{Zn}$ & $\mathrm{Mg}$ & Empirical & Idealized & \\
\hline 1 & 3 & 3 & 4 & 5 & 6 & 7 & 8 & 9 & 10 & 11 & 12 & 13 & 14 & 15 & 16 & 17 \\
\hline 1 & 2 & 1 & & 9935 & & - & - & - & - & - & - & - & 0.65 & & & Native gold \\
\hline 2 & $/ /$ & 2 & - & 72.06 & 20.62 & 3.40 & 3.25 & & - & - & - & - & - & $\begin{array}{l}\mathrm{Ag}_{2.02}\left(\mathrm{Cl}_{1.77}\right. \\
\left.\mathrm{Br}_{0.12} \mathrm{~J}_{0.08}\right)_{1.97}\end{array}$ & $\mathrm{Ag}\left(\mathrm{Cl}_{0.9} \mathrm{Br}_{0.06} \mathrm{~J}_{0.04}\right)_{1.0}$ & Chlorargyrite \\
\hline 3 & $/ /$ & 3 & - & 65.69 & 0.65 & 24.22 & 9.13 & & - & - & 0.31 & & - & $\begin{array}{l}\mathrm{Ag}_{2.61}\left(\mathrm{~J}_{0.82} \mathrm{Br}\right. \\
\left.{ }_{0.49} \mathrm{Cl}_{0.08}\right)_{1.39}\end{array}$ & $\begin{array}{c}\mathrm{Ag}_{1,88}\left(\mathrm{Cl}_{0,06} \mathrm{Br}_{0.35} \mathrm{~J}_{0,59}\right) \\
1.0\end{array}$ & Iodine-bromide \\
\hline 4 & $/ /$ & 4 & 96.62 & 2.44 & 0.63 & - & 0.30 & & - & - & - & - & - & & & $\begin{array}{l}\text { High-grade gold } \\
\text { admixed with } \\
\text { silver } \\
\text { chlorodibromide }\end{array}$ \\
\hline 5 & 3 & 1 & - & 77.24 & 12.04 & - & 10.72 & & - & - & - & - & - & $\begin{array}{c}\mathrm{Ag}_{1.80}\left(\mathrm{Cl}_{0.86}\right. \\
\left.\mathrm{Br}_{0.34}\right)_{1.2}\end{array}$ & $\begin{array}{l}\mathrm{Ag}_{1.50}\left(\mathrm{Cl}_{0.71} \mathrm{Br}_{0.29}\right)_{1.0} \\
\text { или } \mathrm{Ag}_{3}\left(\mathrm{Cl}_{1.42} \mathrm{Br}_{0.58}\right)_{2}\end{array}$ & $\begin{array}{c}\text { Bromine-bearing } \\
\text { chlorargyrite }\end{array}$ \\
\hline 6 & // & 2 & - & 96.56 & 1.04 & - & 2.40 & & - & - & - & - & - & & & $\begin{array}{l}\text { Native silver } \\
\text { with silver's } \\
\text { bromide and } \\
\text { chloride }\end{array}$ \\
\hline 7 & // & 3 & - & 52.45 & - & 46.68 & 0.28 & & 0.58 & - & - & - & - & $\begin{array}{c}\operatorname{Ag}_{1.71}\left(\mathrm{~J}_{1.28} \mathrm{Br}\right. \\
0.01)_{1.29}\end{array}$ & $\mathrm{Ag}_{1.32} \mathrm{~J}_{1.0}$ & Iodyirite \\
\hline 8 & 4 & 1 & - & 99.17 & - & - & - & & - & - & - & - & 0.83 & & & Native silver \\
\hline 9 & // & 2 & - & 51.73 & - & 47.43 & - & & 0.41 & - & - & - & - & $\mathrm{Ag}_{1.12} \mathrm{~J}_{0.88}$ & $\operatorname{Ag}_{1.28} \mathbf{J}_{1.0}$ & Iodyirite \\
\hline 10 & 6 & 1 & 85.27 & 14.73 & - & - & - & & - & - & - & - & - & & & $\begin{array}{c}\text { Moderately } \\
\text { high-grade gold }\end{array}$ \\
\hline 11 & // & 2 & - & 99.23 & - & - & - & & - & - & - & - & 0.77 & & & Native silver \\
\hline 12 & // & 3 & - & 47.80 & - & 52.20 & - & & - & - & - & - & - & $\mathrm{Ag}_{1.04} \mathrm{~J}_{0.96}$ & $\mathrm{Ag}_{1.08} \mathrm{~J}_{1.0}$ & Iodyirite \\
\hline 13 & 7 & 1 & 64.48 & 35.52 & - & - & - & - & - & - & - & - & - & & & Electrum \\
\hline 14 & // & 2 & - & 82.82 & - & - & - & - & 5.44 & 10.04 & 0.51 & - & - & & & $\begin{array}{l}\text { Silver admixed } \\
\text { with iron oxide }\end{array}$ \\
\hline 15 & // & 3 & $96.82-$ & 3.18 & - & - & - & - & - & - & - & - & - & & & High-grade gold \\
\hline 16 & 5 & 1 & & 65.61 & - & - & - & 18.39 & - & - & 16.0 & & & $\begin{array}{c}\mathrm{Ag}_{1.3} \mathrm{Cu} 0.62 \\
\mathrm{~S}_{1.07}\end{array}$ & $\left(\mathrm{Ag}_{1.35} \mathrm{Cu}_{0.65}\right)_{2} \mathrm{~S}$ & Mckinstryite \\
\hline 17 & $/ /$ & 2 & - & 48.79 & - & 1.85 & - & 18.80 & 10.05 & 5.84 & 13.75 & - & - & $\begin{array}{c}\mathrm{Ag}_{1.15} \mathrm{Cu}_{0.75} \mathrm{~S} \\
1.1\end{array}$ & $\left(\mathrm{Ag}_{1.2} \mathrm{Cu}_{0.80}\right)_{2} \mathrm{~S}$ & $\begin{array}{l}\text { Mckinstryite } \\
\text { with Fe oxide }\end{array}$ \\
\hline 18 & $/ /$ & 3 & & 56.33 & - & 41.52 & - & 0.64 & 1.52 & - & - & - & - & $\operatorname{Ag}_{1.23} \mathrm{~J}_{0.77}$ & $\operatorname{Ag}_{1.60} \mathbf{J}_{1.0}$ & Iodyirite \\
\hline 19 & $/ /$ & 18 & 93,09 & 5.88 & - & - & - & - & 1.03 & - & - & - & - & & & High-grade gold \\
\hline 20 & $/ /$ & 19 & - & 90.23 & & - & - & - & 3.45 & 6.32 & & - & - & & & $\begin{array}{l}\text { Silver with } \mathrm{Fe} \\
\text { hydroxides }\end{array}$ \\
\hline 21 & $/ /$ & 20 & 63.70 & 36.30 & & - & - & - & - & - & - & - & - & & & Electrum \\
\hline 22 & $/ /$ & 21 & 46.94 & 53.06 & & - & - & - & - & - & - & - & - & & & Electrum \\
\hline 23 & $/ /$ & 22 & 92.20 & 7.80 & & - & - & - & - & - & - & - & - & & & High-grade gold \\
\hline 24 & $/ /$ & 23 & & & & - & - & - & 0.42 & - & 33.30 & 66.28 & - & $\begin{array}{c}\mathrm{Zn}_{1.48} \mathrm{Fe}_{0.01} \mathrm{~S}_{1} \\
.51\end{array}$ & $\left(\mathrm{Zn}_{0.99} \mathrm{Fe}_{0.01}\right)_{1} \mathrm{~S}$ & Sphalerite \\
\hline 25 & $/ /$ & 24 & & & & - & - & 76.10 & 0.52 & - & 23.29 & - & - & $\begin{array}{c}\mathrm{Cu}_{1.86} \mathrm{Fe}_{0.01} \mathrm{~S}_{1} \\
.13\end{array}$ & $\left(\mathrm{Cu}_{1.65} \mathrm{Fe}_{0 .} 01\right)_{1.66} \mathrm{~S}$ & Geerite \\
\hline
\end{tabular}



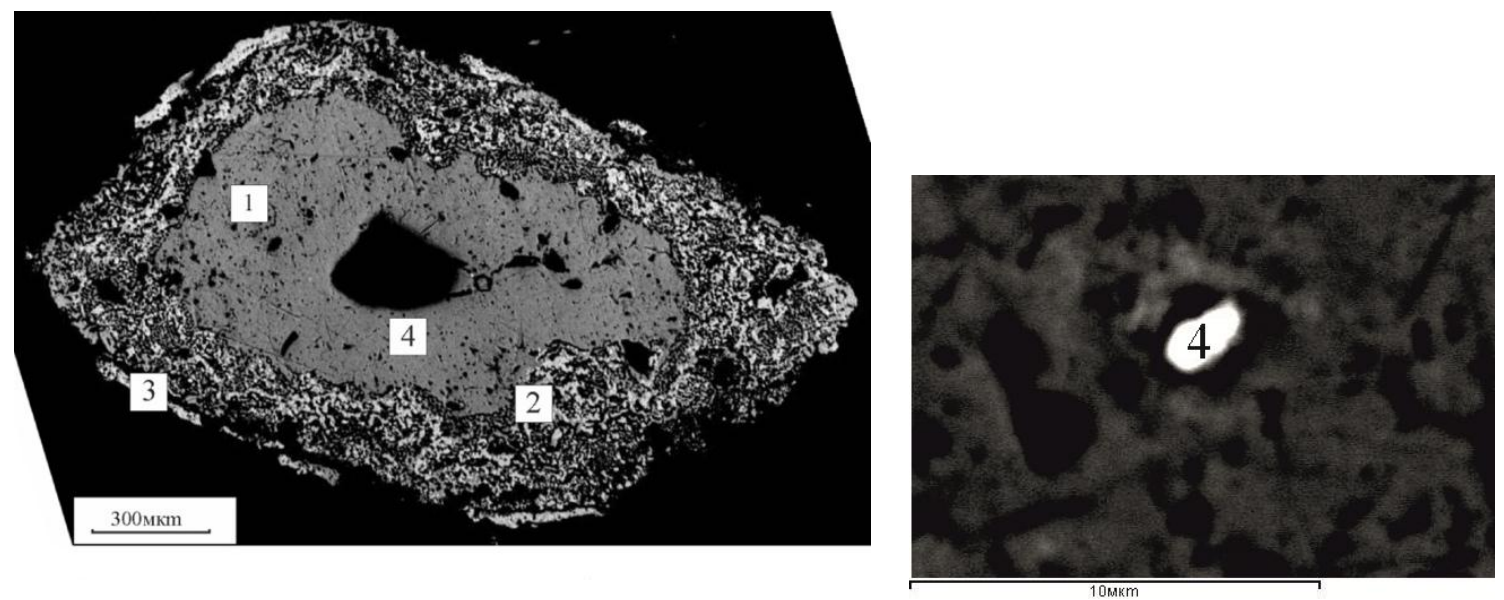

Fig. 2. A zonal accretion. Left: in its core, native silver with inclusion of gold $(1,4)$, framed by chlorargyrite (2), the latter is edged by iodobromite (3). Right: an enlarged fragment of fig. 1 with inclusion of gold within the native silver.

Embolite $\mathrm{Ag}(\mathrm{Cl}, \mathrm{Br})$ is a basis of zonal accretions; thinly framed by iodyrite; also contains thin-grained porous native silver (fig. 3).

Iodyirite AgI develops in zonal accretions in the form of thin rims around embolites, porous native silver, mckinstryite (fig $3-5)$.

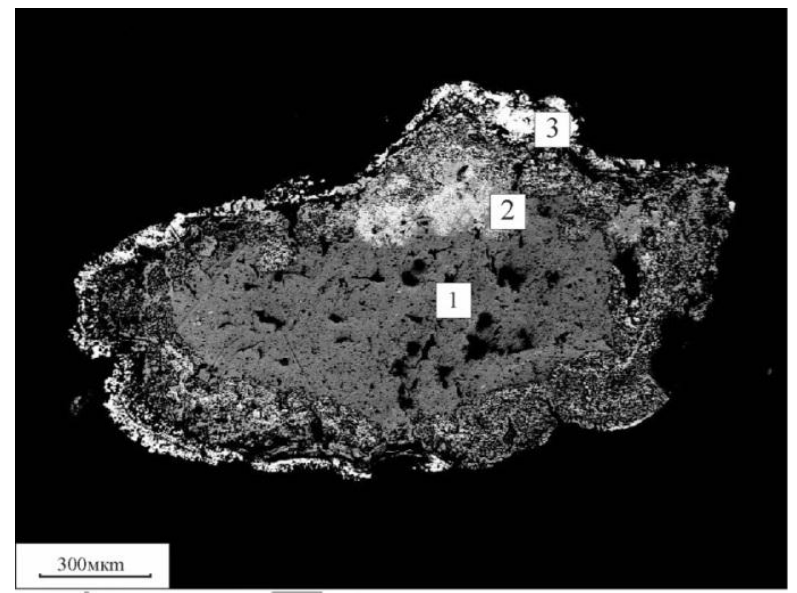

Fig. 3. A zonal accretion; in its core part, the embolite (1) is framed by iodyirite (3); (2) porous inclusion of native silver.

Mckinstryite $(\mathrm{Ag}, \mathrm{Cu}) 2 \mathrm{~S}$ is sulphide of silver and copper, found also in a zonal accretion, its core part is composed of homogenous formation, surrounded by cracked mckinstryite with admixture of iodine, edged by iodyrite (fig. 5).

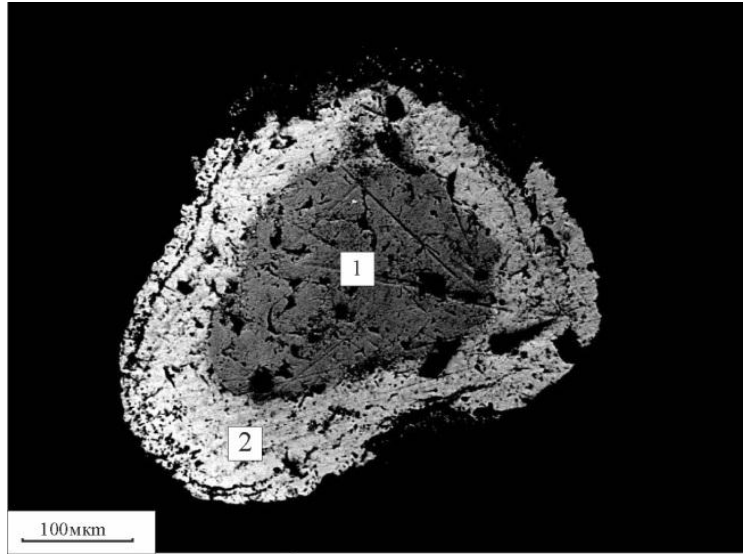

Fig. 4. Porous native silver (1) framed by aggregated porous iodyirite (2). The photo was taken by electron-probe microanalyzer in a back-sparse electron mode.

Native silver and gold. Native silver occurs in zonal accretions with silver halides; usually the latter form thin rims around silver (fig. 2). Porous inclusions of silver are found in embolite (fig. 3). Also detected was porous silver, framed by porous iodyrite (fig. 4). Besides, one can observe native silver of two generations: light-yellow Ag I and surrounding thingrained porous Ag II (fig. 6). Native silver was also noticed in accretions with electrum (fig. 7). Native gold is in subordinate quantity; its small inclusions were identified in native silver (fig. 2, 6, 7). Gold is of high-grade. Along with native silver, accretions contain electrum (fig. 7). 


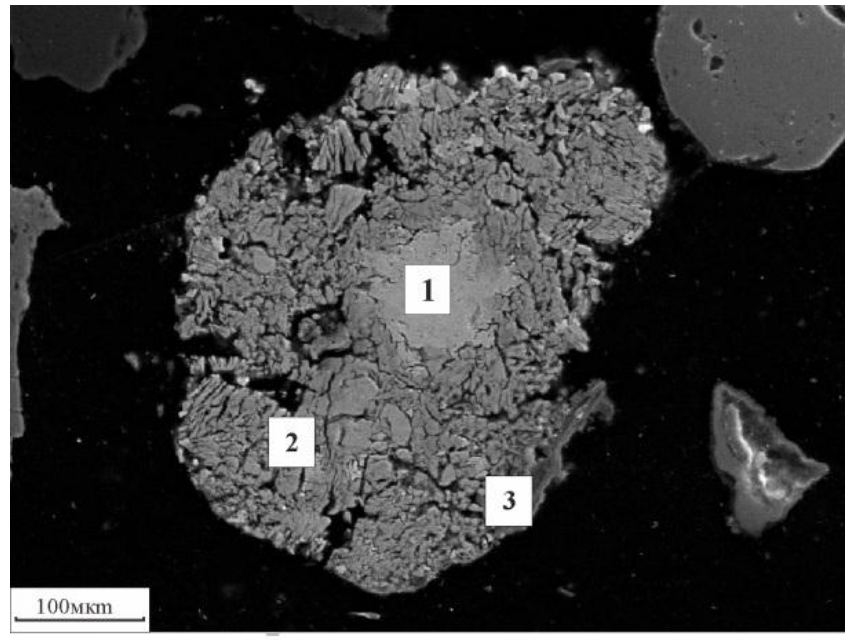

Fig. 5. A zonal accretion consisting of mckinstryite in its core part (1), framed by mckinstryite admixed with iodine (2) and edged by iodyirite (3). The photo was taken by the electron-

probe microanalyzer in a back-sparse electron mode.

The study of silver halides and noble metals from the oxidation zone was carried out, under the guidance of Dr. Dolgopolova A.V., with the scanning microscope Zeiss EVO 15LS under changing pressure (fig. 8-11 of briquettes) in the Department of Earth Sciences of the Natural History Museum

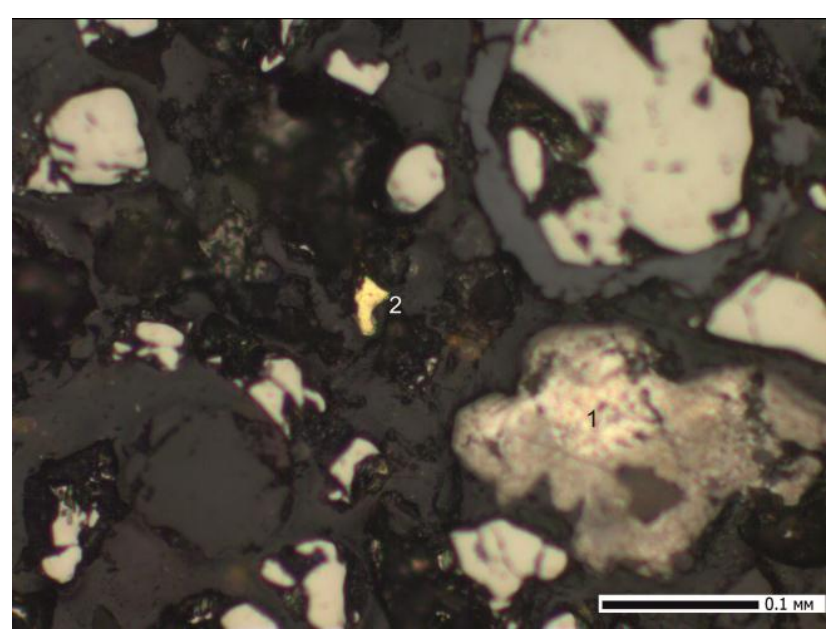

Fig. 6. Light-yellow Ag I (1), overgrown by a porous AgII. Yellow high-grade gold (2).
(London, UK). The results of the study, given in the table 2 and figures $12-17$, confirm the microprobe data, obtained by the author of the work in the Satpayev Institute of Geological Sciences.

\section{INTERPRETATION}

Close paragenesis of gold, silver and silver halides indicates the hypergene nature of gold. The presence of silver halide minerals, especially, silver bromides and iodides in the oxidation zone of the Arkharly deposit is the most reliable proof of its formation in dry and hot climate. Formation of native gold in the zone of hypergenesis is connected to goldenriched sulphate-chloride waters, which, while being filtrated into deeper horizons of the oxidation zone, become less oxidizing, and influenced by various reducing agents are destroyed to form native gold. On the basis of data obtained on silver halides of the oxidation zone of the Arkharly deposit field and supported by data received by other researchers in the study of oxidation zones of gold-sulphide deposits, it is possible to state univocally, that the source of silver in halide minerals is homogenous silver and gold, as well as silvercontaining sulphides.

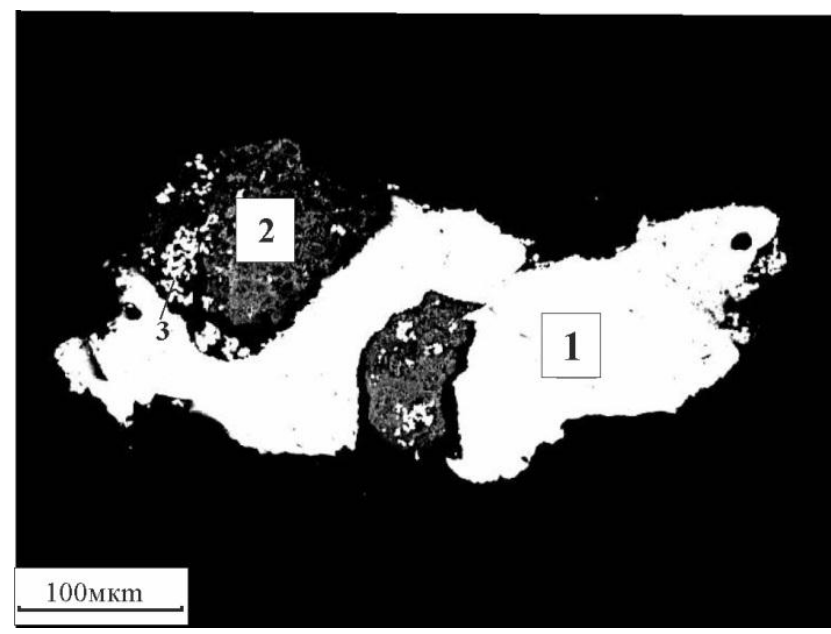

Fig. 7. Growth of electrum (1) and native silver (2) with very fine inclusion of high-grade gold (3). The photo was taken by the electron-probe microanalyzer in a back-sparse electron mode. 


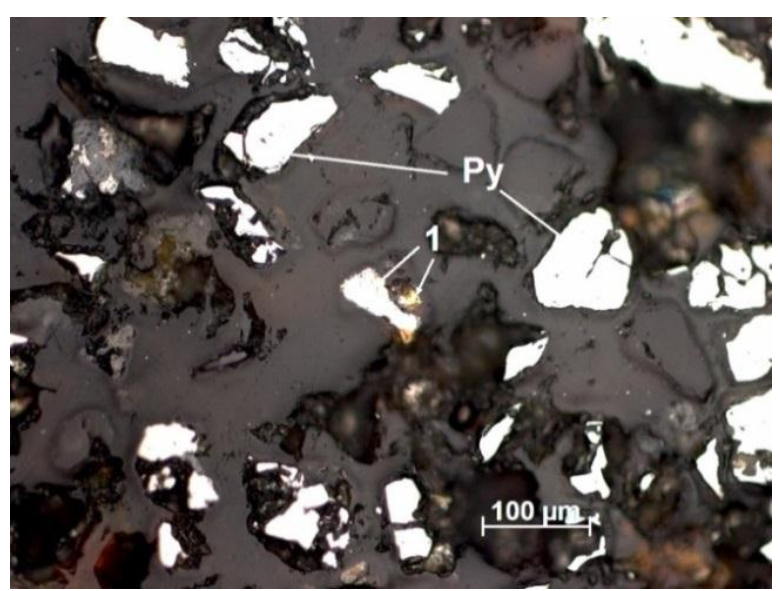

Fig. 8. Briquette 9-8-1

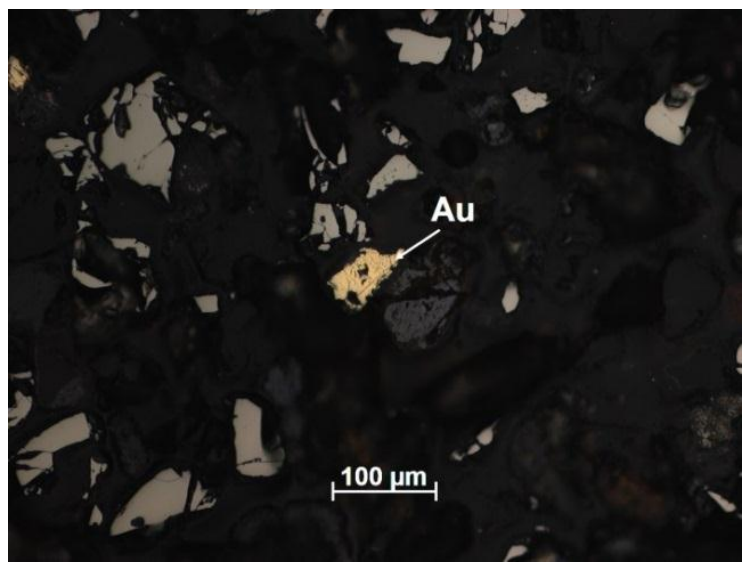

Fig. 10. Briquette 9-8-3

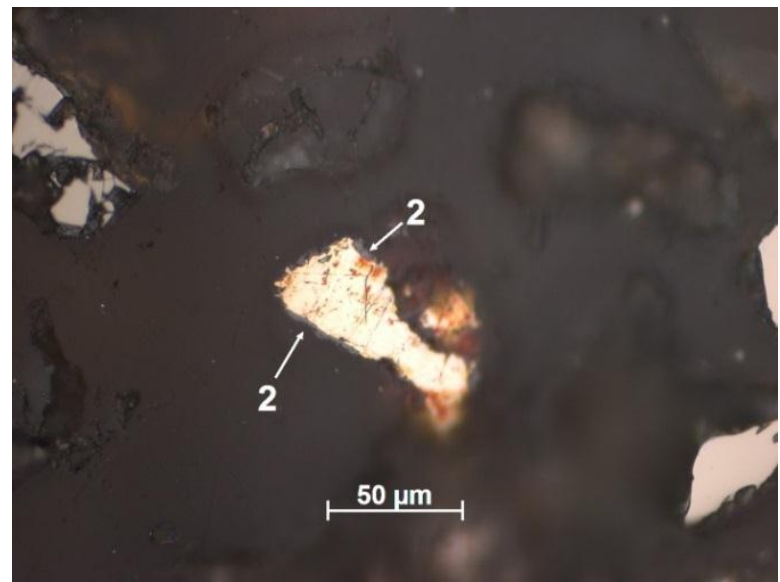

Fig. 9. Briquette 9-8-2

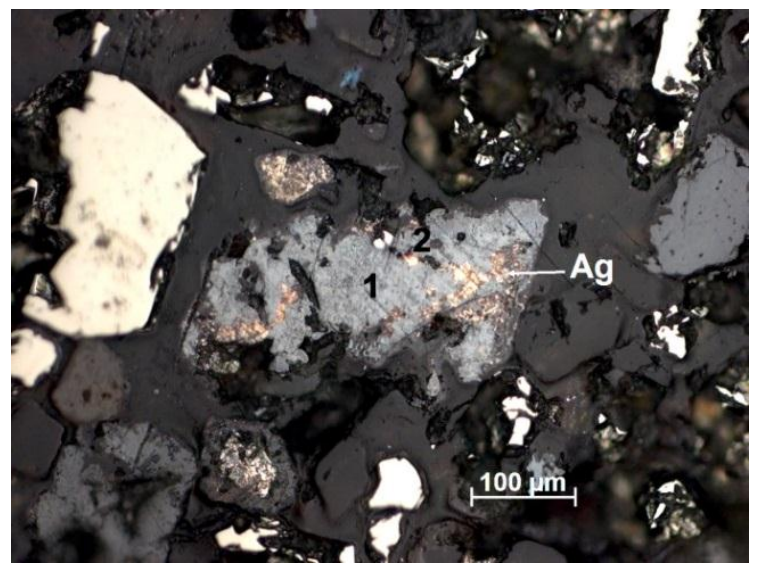

Fig. 11. Briquette 9-8-4

Table 2. Composition of minerals in the oxidation zone

\begin{tabular}{|c|c|c|c|c|c|c|c|}
\hline \multirow[t]{2}{*}{ no. } & \multicolumn{6}{|c|}{ Elements (weight \%) } & \multirow[t]{2}{*}{ Total } \\
\hline & $\mathrm{Ag}$ & $\mathrm{Au}$ & $\mathrm{Cl}$ & $\mathrm{Br}$ & I & $\mathrm{Fe}$ & \\
\hline 1 & 67.13 & - & 15.73 & 14.59 & - & - & 97.45 \\
\hline 2 & 52.05 & - & - & - & 45.54 & 1.23 & 98.82 \\
\hline 3 & 58.12 & - & - & 4.85 & - & 8.51 & 71.48 \\
\hline 4 & 82.67 & - & 9.92 & 7.81 & - & - & 100.40 \\
\hline 5 & - & 101.21 & - & - & - & - & 101.21 \\
\hline 6 & 37.94 & 63.27 & - & - & - & - & 101.21 \\
\hline 7 & 49.14 & - & - & - & 50.55 & - & 99.69 \\
\hline
\end{tabular}

Bromine-containing chlorohydrite. Analysis 1 (Spectrum 1)

1) Bromine-containing chlorohydrite; 2) Iodyiritis; 3) Bromine-containing native silver; 4) Bromine-containing chlorargyrite;

5) Native gold of a very high standard; 6) Electrum; 7) Iodiritis.

Scanning microscope "Zeiss EVO 15LS" (London, UK) 


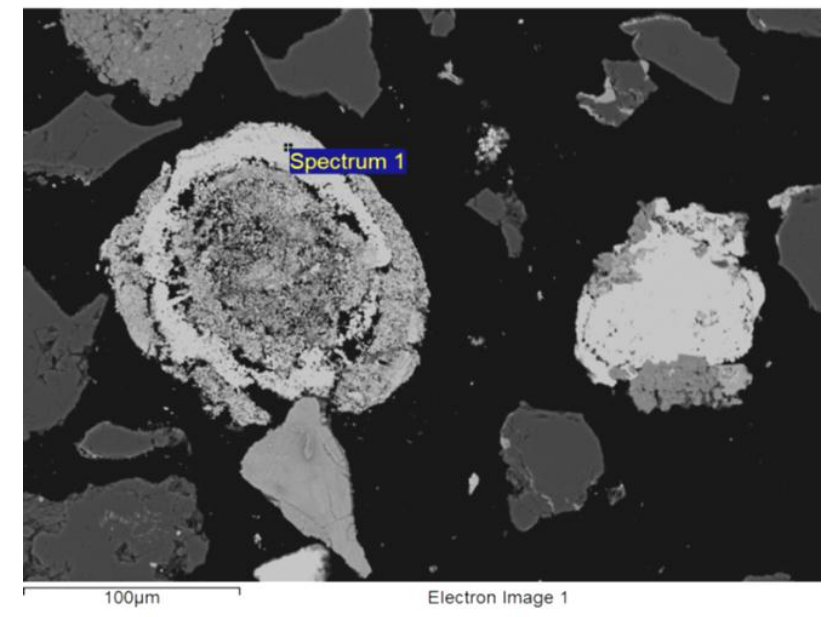

Fig. 12. Iodyrite. Analysis 2 (Spectrum 1).

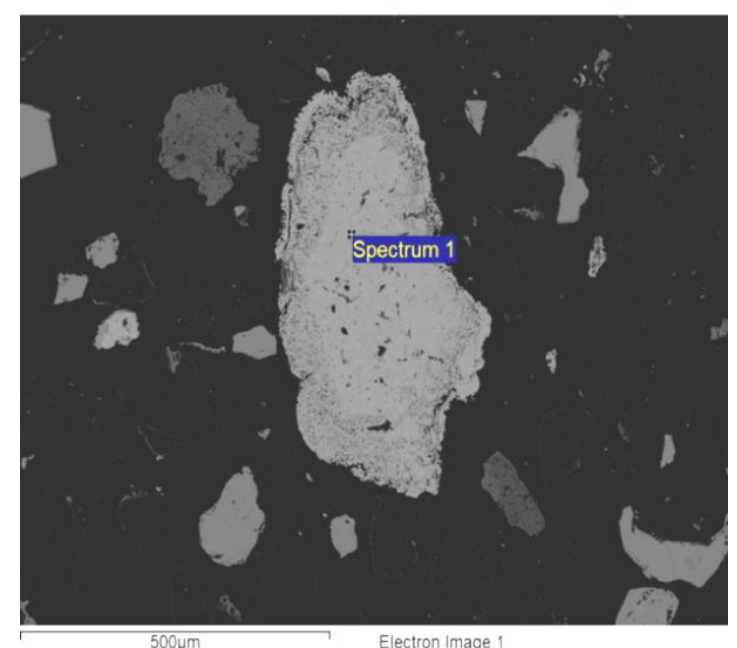

Fig. 14. Bromine-bearing chlorargyrite. Analysis 4 (Spectrum 1).

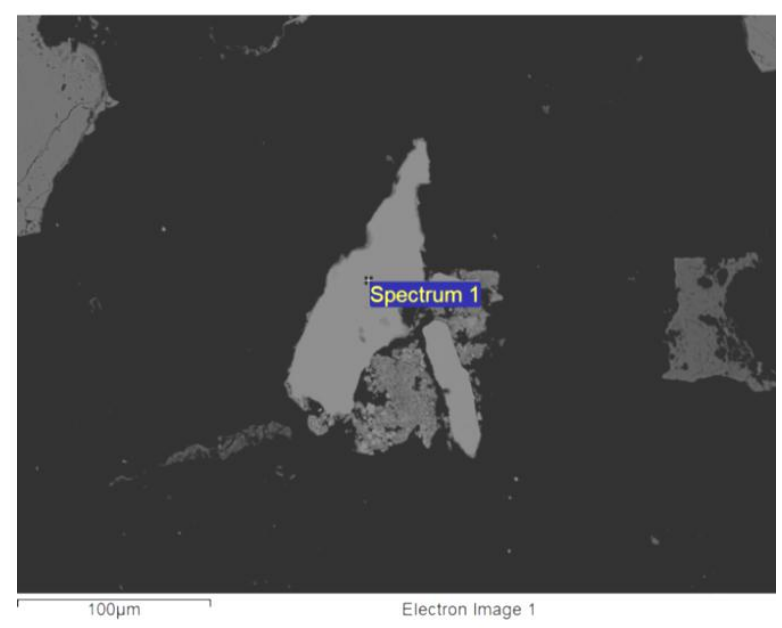

Fig. 16. Electrum. Analysis 6 (Spectrum 1).

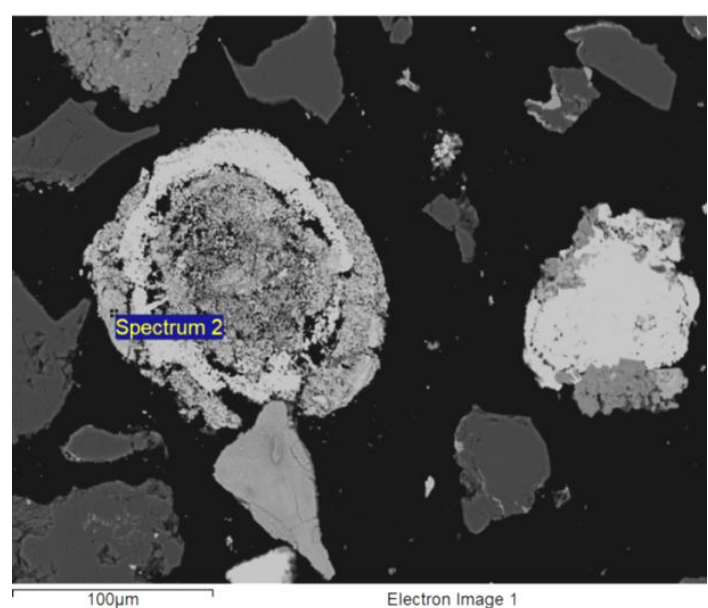

Fig. 13. Bromine-bearing native silver? Analysis 3 (Spectrum 2).

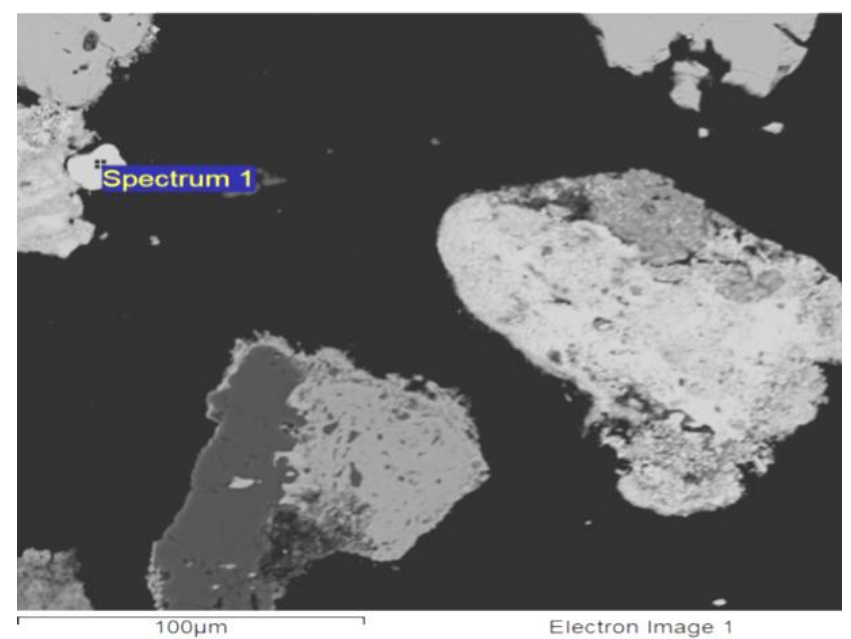

Fig. 15. Native gold of a very high standard. Analysis 5 (Spectrum 1).

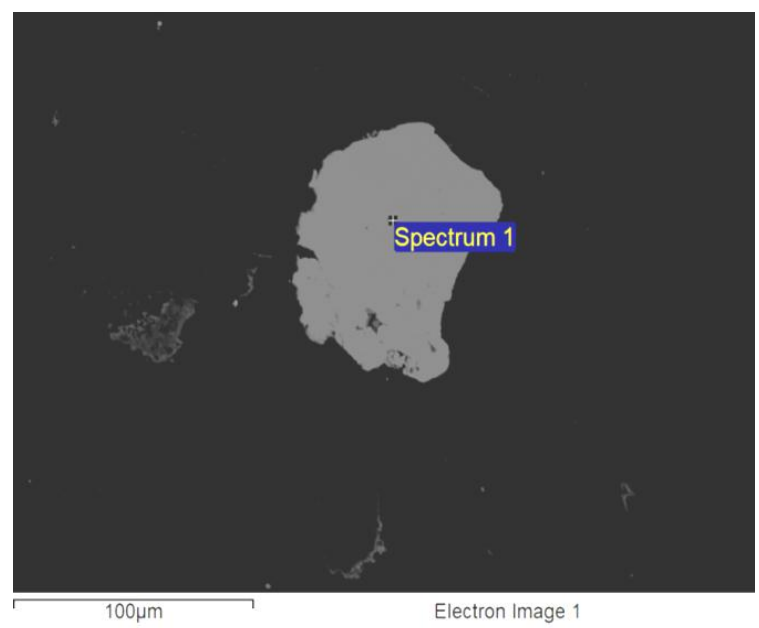

Fig. 17. Iodyrite. Analysis 7 (Spectrum 1). 
The oxidation zone also contains hypergene sulphides of copper (covelline, chalcosine, bornite), gematite and iron hydroxides (goethite, hydrogoethite). Covelline forms mainly rims, micro veins and fine releases in chalcopyritee, partly or fully replacing the latter. Chalcosine is less common than covelline, but usually is closely associated with it. Sometimes it replaces sphalerite and bornite, forming rims and penetrating the latter through weakened zones [12-15].

Detailed study of the formation features of hypergene gold and silver in the oxidation zone has both theoretical and applied value. It is necessary for deciphering the behaviour of gold and silver in bearing solutions and for defining their physical and chemical parameters. It would also be useful in finding solutions to practical issues of development of new technologies of gold and silver recovery.

\section{CONCLUSION}

Presence of silver halide minerals, especially, silver bromides and iodides, in oxidation zones of the Arkharly deposit is the most reliable proof of its formation in dry and hot climate. Formation of native gold in the zone of hypergenesis is associated with gold-enriched sulphate-chloride waters, which, as filtrated into deeper horizons of the oxidation zone, become less oxidising and influenced by various reducing agents, are destroyed to form native gold. On the basis of data obtained on silver halides of the Arkharly oxidation zone and supported by results of other researchers concerning the oxidation zones of gold-sulphide deposits it is possible to state unequivocally, that silver of halide minerals originates from native (homogenous) silver and gold, as well as silver-containing sulphides.

\section{REFERENCES}

[1] Zhautikov TM et al. Features of hypergenesis at goldsilver deposits of Southern Dzungaria (Kazakhstan). The Siberian Gold: geology, geochemistry, technology, economics. Works of the Second International Symposium. Krasnoyarsk. 2001: 205-206.

[2] Narseyev VA. Industrial geology of gold. Moscow: "Nauchnyj Mir". 1996: 243.

[3] Grebenchikov AM. Mineralogical and geochemical features of near-surface gold ore deposits of the Late Paleozoic volcanic belt of Kazakhstan. Dissertation abstract of Aspirant in Geol.-Min. Sc. Moscow. 1976: 24.

[4] Shcherbakov YuG, Roslyakova NV, Radosteva NE. Fractioning as the basis for genetic models of gold ore formations. Genetic models of gold ore formations. Theses from the All-Union conference report, 20-22 May 1981. Novosibirsk. 1981; 2: 146-148.

[5] Radtke AS. Geology of the Carlin gold deposit, Nevada. US Geol. Surv. Proffess. Paper. 1985; 1267.

[6] Shilo AN, Saharova MS, Batrakova YuA et al. Osobennosti soosazhdenija zolota i serebra pri povyshennyh temperaturah $\left(100-200{ }^{\circ} \mathrm{C}\right)$ [Features of co-sedimentation of gold and silver under increased temperatures (100-200 $\left.\left.{ }^{\circ} \mathrm{C}\right)\right]$. DAN SSSR. 1980; 255 (1): 195-197.

[7] R. Brauns. Chemical mineralogy. Saint Petersburg. 1904

[8] Geology of Australian ore deposits. 2-nd ed. Eighth Commonw. Min and Metall. Congress, Australia and New Zealand. Melbourn. 1965; 1.

[9] Umarbekova ZT, Plekhova KR, Dyussembayeva KSh. The halides of silver in the hypergene zone gold-silver deposit Arkharly (South Zhongar) Series of Geology and Technical. Almaty, NAS March-April, 2018. 2018; 2(428): 141-148

[10] Seltmann R, Shatov V, Yakubchuk A. GIS package on mineral deposits database and thematic maps of Central Eurasia. In: Mineral Deposit Research: Meeting the Global Challenge. Springer, Berlin, Heidelberg. 2005: 1331-1334. https://doi.org/10.1007/3-540-27946-6_339

[11] Zhautikov TM, Skrinnik LI, Umarbekova ZT, Gadeev RR. Geological map of the Arkharlinsky ore field. CorelDROWX7. Satbayev University, Institute of Geological Sciences named after Satbayev, Almaty, Kazakhstan. 2014.

[12] Seryh VN. Tectonic position and granitoides genesis of Kazakhstan polycyclyc fold region. Smyrnov collection, 2018: 257-286.

[13] Skrinnik LI. To Paleogeodynamics of southeastern Kazakhstan. News NAS RK. Series geology and technical sciences. 2016; 5: 50-61.

[14] Uzkenov BS. The mineragenic map of Kazakhstan Explanatory note. Almaty, 2007: 97-105.

[15] Bonin B, Azzouni-Sekkal A, Bussy F, Ferrag S. Alkalicalcic and alkaline post-orogenic (PO) granite magmatism: petrologic constraints and geodynamic settings. Lithos, 1998; 45(1-4): 45-70. https://doi.org/10.1016/S0024-4937(98)00025-5 